Т. И. Бармашова, П. В. Ломанов. Понятие «соборность» в русской философии

УДК $1: 3$

DOI: 10.18101/1994-0866-2020-1-73-80

\title{
ПОНЯТИЕ «СОБОРНОСТЬ» В РУССКОЙ ФИЛОСОФИИ
}

\author{
(C) Бармашова Татьяна Ивановна \\ доктор философских наук, профессор, \\ Красноярский государственный аграрный университет \\ Россия, 660049, г. Красноярск, просп. Мира, 90 \\ E-mail: tatibar910@mail.ru

\section{(C) Ломанов Павел Владимирович} \\ кандидат культурологии, преподаватель лицея № 28, \\ Россия, 660021, г. Красноярск, ул. Профсоюзов, 17 \\ E-mail: lpv79@mail.ru
}

В статье рассматривается понятие «соборность» в русской философии, отражающее один из главных принципов общественной интеграции - принцип духовной общности людей как в религиозном, так и в светском контекстах. Концепция соборности в русской философии утверждает нормы высшей морали, выражающие развитое самосознание и самоопределение личности в соборном опыте как продвижение к Божественной истине. Подобная интерпретация дает возможность постижения метафизических глубин личности, представляющих собой ее сущностные стороны. Идея соборности оказывает значимое влияние на развитие гуманитарного знания. Подчеркивается определенная схожесть идеи соборности и философских концепций диалога и коммуникации западных мыслителей ХХ в.: от представителей религиозного экзистенциализма (М. Бубер, К. Ясперс, Э. Левинас) до социологических и социально-философских теорий общества, в которых центральное место отводится коммуникации (Т. Парсонс, Р. Мертон, Н. Луман, Ю. Хабермас). Идея соборности имеет большое практическое значение. Принцип соборного устройства общества может стать средством гармоничной консолидации людей, основой для становления национального единства российского государства.

Ключевые слова: соборность; коммуникация; диалог; общество; экклезиология; богословие; социальная философия; русская философия; религиозная философия; церковь; идентичность; жизненный мир; система.

\section{Для цитирования}

Бармашова Т. И., Ломанов П. В. Понятие «соборность» в русской философии // Вестник Бурятского государственного университета. Философия. 2020. Вып. 1. C. $73-80$.

Особенностью понятия «соборность» является то, что оно характерно лишь для русской философии. Вместе с тем отголоски идеи соборности можно обнаружить в концепциях ряда современных западных мыслителей. Этот момент обычно не является предметом рассмотрения в исследованиях соборности. В этом отношении целью статьи является не только анализ понятия «соборность» в отечественной философии, но также рефлексия определенных паралле- 
лей между данным понятием и философско-социологическими концепциями диалога и коммуникации западных мыслителей XX в. Исследователь отечественной философской традиции С. С. Хоружий обращает внимание на неоднозначность трактовки понятия «соборность» в русской философии: оно употребляется в двух основных контекстах - богословском (соборность как принцип организации церкви, указанный в Никео-Константинопольском символе веры) и социальном (как характеристика того или иного общества, принцип единения человеческих личностей) [19]. В подобном ключе некоторые исследователи определяют соборность как понятие духовное, религиозное и философское [10].

В чисто религиозном аспекте соборность представлена в философии А. С. Хомякова, С. Н. Булгакова. К. С. Аксаков сводит смысл соборности к общинности, иными словами, социологизирует данное понятие. В концепции С. Л. Франка понятие соборности определяется шире, имеет не только религиозный оттенок, отражая также внецерковную социальную общность индивидов, но и в целом принципы общественной интеграции. В. С. Соловьев, С. Н. Трубецкой, Л. П. Карсавин подходят к проблеме соборности в контексте концепции всеединства.

Понятие «соборность» было введено в философский дискурс в качестве чисто богословского, церковного понятия А. С. Хомяковым. Причем у него оно используется как прилагательное - «соборный». Существительное «соборность» было сконструировано позже в отечественной публицистике конца XIX в. Источником данного понятия служит славянский перевод церковного экклезиоло-

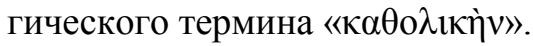

Соборное единство выражает не только любовь и свободу в единении членов церкви, но и обоснование роли самой церкви, как преобразующей историю силы. Хомяков достаточно сложно представляет механизм взаимодействия индивидуального и коллективного сознания. Соборное единство, в его понимании, преодолевает недостатки индивидуализма и коллективизма, синтезируя их достоинства. Духовное единение с церковью одновременно соборно и индивидуально. Только целостный церковный разум способен постичь высшую истину.

Философ видит отличительную особенность веры в том, что она не сводится к исключительно логическому и рациональному полаганию, предполагая чувства и переживания. Ограниченность рационального познания он объясняет тем, что Божественная истина не укладывается в границах логического постижения. В этом отношении философ придает большое значение целостному знанию, являющемуся, по сути своей, знанием непосредственным, интуитивным. Рассудочность и рационализм в противовес этому он считает препятствием на пути к целостности духовных потенций человека и к познанию истины [18, с. 51]. При этом философ не отвергает законов логики в Божественной истине, подчеркивая лишь абсолютизацию логического познания, исключающего другие виды познания.

К. С. Аксаков в какой-то мере отходит от религиозного контекста понятия «соборность» и фактически отождествляет его с понятием «община». Являясь 
сторонником соборности, мыслитель предостерегает от самообособления личности, которое выступает причиной ее саморазрушения. Альтернативным путем он считает самоограничение в пользу единого целого, ведущего к гармонии и высшему типу организации социума, то есть к общине. Как славянофил Аксаков идеализирует общину и видит в ней особый путь развития России. В общине мыслитель отмечает много положительных качеств и преимуществ. Как он полагает, в русской общине не исключается возможность проявления свободы, внутренней жизни личности. Она ограничивает лишь негативные проявления человеческого поведения - эгоизм, дебоширство, разнузданность и прочее. Вместе с тем община не препятствует свободному волеизъявлению личности, если оно не выходит за рамки общепринятых норм поведения [1]. Аксаков фактически переводит понятие «соборность» в социологическую плоскость.

В отличие от К. С. Аксакова, С. Н. Трубецкой развивает религиозную линию А. С. Хомякова, создав своеобразное учение («гипотезу», по его терминологии) о «соборной природе сознания». Проблему соборности он решает в контексте проблемы сознания исходя из нетождественности личностного сознания и человеческой индивидуальности. В понимании Трубецкого, сознание интерсубъектно, оно не ограничивается субъективным содержанием, не является абсолютно изолированным. «Чужие я» во многом определяют наше сознание и в том числе мораль как одно из проявлений его бытия. Вся духовная жизнь человека, предполагая значимость индивидуально-личностных переживаний, неизбежно ориентирована на Других. Как полагал философ, мы «держим внутри себя сбор со всеми» $[15$, c. 495]. Проекция духовного мира личности на других трактуется Трубецким с позиций трансцендентализма.

Сознание философ не сводит к личностному феномену, считая его соборным. Понимая сознание метафизически, мыслитель связывает источник сознания со «вселенским началом», именуемым также «вселенским сознанием» и «универсальным субъектом», который является предпосылкой любого отдельного сознания. Универсальный субъект не тождествен Абсолюту или Богу. Это некое универсальное психофизическое космическое Существо, подобное понятию мировой души Платона. Важной целью человека Трубецкой считает достижение «потенциальной соборности». Иными словами, соборность для него является не воплощенной реальностью, а этическим идеалом, стимулом развития и самосовершенствования.

В религиозном контексте решает проблему соборности С. Н. Булгаков. Проблему соборности он позиционирует, прежде всего, с гносеологических позиций. Церковь как оплот соборности он считает важнейшим средством постижения сущностных сторон бытия, пониманию единства людей в любви и во Христе. Церковная соборность фактически восполняет пробелы индивидуального сознания. Мыслитель подчеркивает роль соборности в степени церковного постижения, поскольку познание Божественной истины возможно лишь в единении со всеми в церкви. Отдельный человек не способен отразить всю полноту вероучения. Это под силу только церкви, объединяющей верующих в единое целое. Со- 
борность предполагает опознание Слова Божия в истории церкви, основывающейся на опыте поколений. Суть соборности философ связывает с духовной жизнью, с растворенностью личного духа в многоединстве, слитности «я» и «мы» в церковной жизни, в конечном счете с Духом Божиим [13, с. 155].

Аналогично А. С. Хомякову С. Н. Булгаков полагает, что соборность невозможно понять, исходя из рационального. В механизме формирования соборного сознания С. Н. Булгаков отдает приоритет интуитивному постижению. В силу своей интуитивной природы церковная соборность проявляется в жизни, в действии (молитва и созерцание) раньше, чем в сознании. Соборное сознание сверхличностно, поскольку истина достижима только в церковном единении.

Механизм приобщения индивидуального сознания к соборному сознанию С. Н. Булгаков понимает диалектически и метафизически. Проблема взаимосвязи индивидуального и соборного сознания у С. Н. Булгакова приобретает трансцендентальное звучание. Соборный, сверхличностный опыт, выражающий высшую духовную действительность, становится личным. Личное самосознание и личное богословствование стремятся отождествить свою веру с сознанием сверхличным, соборным, церковным [13, с. 169-171].

Осознанное, осмысленное приобщение к соборному церковному опыту не только делает человека свободным, но и приближает к Божественной истине. Соборная жизнь в церкви, олицетворяющей тело Христово, дарует истинную жизнь, наполненную истинным самосознанием, и самоопределением. Только в соборности Булгаков видит возможность идентификации личности себя самой с Творцом и Логосом. Духовное богоподобие человека не ограничивается стремлением к высшей истине, добру и красоте. Оно в первую очередь ассоциируется с ипостасным божественным триединством, выражаясь в принципе церковной соборности как единство «я», «ты» и «мы» $[13$, с. 232]. Религиозная интерпретация соборности имеет место и в современных отечественных исследованиях [3].

В отличие от А. С. Хомякова и С. Н. Булгакова, у С. Л. Франка «соборность» становится универсальным социологическим понятием. Если Хомяков связывал организационный принцип соборности с бытием церкви как особого христианского социума, единения в Духе и во Христе, то Франк понимал соборность как один из главных организационных принципов общественной жизни, самого социального существования человека. Причем этот принцип у Франка следовал из базового концепта «положительного всеединства», заданного В. С. Соловьевым. Он раскрывает понятие «соборность» своеобразно. Согласно С. Л. Франку, «соборность» является внутренней сущностью, основным принципом бытия любого общества, определяющим неразрывное единство человеческого «я» и «ты», образующих «мы» [16, с. 61].

Осуществляя понятийный анализ, С. Л. Франк разграничивает понятия «соборность» и «общественность». При этом он их не противопоставляет, а только подчеркивает принадлежность к различным типам интеграции социума. Соборность представляет собой внутренний принцип общности людей. «Общественность» реализуется вовне, существует посредством механического принципа 
объединения на основе единых целей, интересов и тому подобное [16, с. 67]. Другим важным моментом мыслитель полагал вневременность соборного единства.

У русского философа Л. П. Карсавина идея соборности разворачивается на основе метафизики всеединства как идея связи Бога с человеком, которая находится в самом Боге. Для раскрытия этого феномена философ использует понятия «другой», «иной», соотносительные с понятием «абсолют». Тайну всеединства философ видит в метафизике любви, которая определяет единство человечества, единство тела Христа и церкви. Только в Христе и в лоне церкви, в единстве с другими человеческая личность приобретает истинное бытие. Человек понимается Карсавиным как космос, как единство тварного бытия, заключенного в мировой душе. По мнению мыслителя, все сотворено во Всеедином человеке, но человек по причине своей слабости подвержен распадению на отдельного человека и мир, на душу и тело. По причине индивидуализации происходит отпадение людей от Бога. Только Бог (Абсолют) олицетворяет собой совершенное всеединство. Человек же проявляет себя как несовершенное, становящееся существо.

Преодолению этого недостатка служит симфоническая (соборная) личность - некая целостная гармоничная общность людей, главной целью которой является самосовершенствование и на этой основе обожение людей, приближение к божественному совершенству. В этом отношении каждая личность является элементом церковного единства. Одновременно церковь представляет собой всеобъемлющую личность [6]. Таким образом, Карсавин диалектически решает вопрос о симфонической личности как неразрывном триединстве: первоединство - саморазъединение - самовоссоединение и остается последовательным и верным сторонником концепции всеединства В. С. Соловьева.

Определенную близость к идее соборности в русской философии можно обнаружить в построениях немецких философов и социологов XX в. И это, видимо, не случайно. Всегда существовали тесные связи между русской и немецкой философской традицией и культурой. Дискурс русской философии диалогичен. В этом отношении представляется правомерным провести определенные аналогии с социологическими, гносеологическими, онтологическими, теологическими концепциями диалога более поздних мыслителей - М. Бубера, К. Ясперса, Э. Левинаса. В их концепциях диалог «я» и «ты» является необходимой предпосылкой «со-бытия» людей, интегрирующей общество, что, несомненно, напоминает идеи русских философов в учении о соборности.

Концепция Н. Лумана, интерпретирующая общество в качестве самореферентной системы, имеющей способность самовоспроизведения через коммуникацию [8], также позволяет заметить интенции, близкие к построениям концепции соборности. Хотя понятия «коммуникация» и «диалог» не озвучиваются в учении о соборности, но фактически подразумеваются в нем. По сути, русская философия, опережая создание данных концепций посредством понятия «соборность» как важного принципа коммуникации социума, сформировала такое понимание общества, которое в определенной степени способствовало позднее 
обоснованию теории систем в современной социологии (Т. Парсонс, Р. Мертон, Н. Луман и др.).

Идею соборности перспективно рассмотреть в рамках теории коммуникации современного немецкого философа и социолога Ю. Хабермаса. Прежде всего, вызывает интерес дихотомия «жизненный мир» - «система», играющая важную роль в его учении об обществе [17]. Феноменологическое понятие «жизненный мир» Ю. Хабермас наполняет социологическим содержанием. Подобно понятию «общественность» С. Л. Франка, понятие «системы» Хабермаса является в какойто степени внешней реальностью по отношению к индивиду. Общность «жизненного мира» консолидирует индивидов аналогично «соборности», существующей в обществе как некий внутренний принцип организации. При этом дихотомия Ю. Хабермаса «жизненный мир» - «система» не универсальна, поскольку применима для описания западного общества. В противовес этому дихотомия Франка фактически является универсальной. Помимо этого философ рассматривает «соборность» и «общественность» не в качестве антиподов, а как внутренний и внешний принципы интеграции общества.

Идею соборности в русской философии трудно переоценить. И это не суть важно, в каком аспекте она эксплицировалась - гносеологическом (С. Н. Булгаков, А С. Хомяков), социологическом (К. С. Аксаков, С. Л. Франк), как сугубо церковная реальность, организационный принцип церкви (С. Н. Булгаков, А. С. Хомяков), в контексте концепции всеединства (В. С. Соловьев, С. Н. Трубецкой, Л. П. Карсавин) или основание самого общественного бытия (С. Л. Франк). В любом случае понятие соборности, имея значимый эвристический потенциал, может служить методологическим ориентиром, направляющим познание процессов социальной интеграции, развивая идеи социальной коммуникации.

Значение концепции соборности заключается также в утверждении норм высшей морали, раскрывающейся в процессе формирования развитого самосознания и самоопределения личности в соборном опыте, тем самым способствует постижению метафизических глубин личности.

Концепция соборности важна и в практическом плане. Она способна преодолеть эгоцентрический индивидуализм, который является причиной духовномировоззренческого кризиса [4]. Неслучайно этот момент затрагивается в современных исследованиях соборности, связанных с проблемой возрождения Российского общества. Принцип соборности в церковном опыте и в межчеловеческих отношениях может сыграть основополагающую роль в становлении национального единства. Отечественные авторы все чаще ведут речь об этом [5; 12]. Проблема соборности трактуется в контексте русской национальной идентичности как основа духовной самобытности, нравственный идеал и доминанта русской культуры [2; 7; 9; 11].

Более того, принцип соборности важен в деле гармонизации человеческих взаимоотношений и за пределами определенных национальных рамок. В. С. Соловьев усматривал миссию христианства в том, чтобы в согласии с другими 
народами положить все свои силы на осуществление совершенного и вселенского единства человеческого рода, непреложное основание которого дано нам в церкви Христовой $[14$, с. 632]. Иными словами, философ ведет речь не только о национальном принципе соборности, но также наполняет это понятие общечеловеческим содержанием. Таким образом, соборность оправданно рассматривать в качестве универсального способа интеграции социума, принципа духовной общности людей.

\section{Лuтература}

1. Аксаков К. С. Государство и народ. М.: Изд-во Ин-та русской цивилизации, 2009. $608 \mathrm{c}$.

2. Аралова Е. В. Соборность как фактор духовной культуры России // Власть. 2014. № 7. C. $130-134$.

3. Барсуков Г. В. Религиозно-философская сущность соборности // Система ценностей современного общества. 2013. № 29. С. 7-11.

4. Бондаренко А. Д. Духовно-мировоззренческий кризис современного православного общества как следствие индивидуализации сознания личности и трансформации понимания церковной жизни // Научные ведомости Белгородского государственного университета. Сер. Философия. Социология. Право. 2017. № 10 (259). С. 127-129.

5. Ильин А. Н., Данилова И. Ю. Онтологическое осмысление соборности // Теория и практика современного профессионального образования. 2016. № 1. С. 173-178. $325 \mathrm{c}$.

6. Карсавин Л. П. Религиозно-философские сочинения. М.: Ренессанс, 1992. Т. 1.

7. Кохичко А. Н. О принципах соборного отношения к миру как основе самоопределения личности в русской национальной культуре // Общие вопросы мировой науки. Самара, 2017. С. 25-31.

8. Луман Н. Введение в системную теорию. М.: Логос, 2007. 360 с.

9. Михайлова О. В. Соборность как нравственный идеал традиционной русской культуры // Вопросы современной науки: новые перспективы: сб. ст. междунар. науч.практ. конф. Самара, 2017. С. 59-60.

10. Мищенко А. В. О соборности как понятии духовном, религиозном и философском // Вестник Мурманского государственного технического университета. 2011. Т. 14, № 2. C. 319-324.

11. Монина Н. П. Аксиология соборности русской цивилизации // Научный диалог: Вопросы философии, социологии, истории, политологии: сб. науч. тр. по материалам III Междунар. науч. конф. СПБ., 2016. С. 6-8.

12. Мурзанова Л. А. Соборность как доминанта русской самобытности в социальной философии // Экономические и гуманитарные науки. 2017. № 9 (308). С. 3-11.

13. Прот. Сергий Булгаков. Православие. Очерки учения Православной церкви. Paris: Ymca-Press, 1985. 405 c.

14. Соловьев В. С. Спор о справедливости: сочинения. М.: ЭКСМО-Пресс, 1999. 864 c.

15. Трубецкой С. Н. О природе человеческого сознания // Соч. М.: Мысль, 1994. C. 483-592.

16. Франк С. Л. Духовные основы общества. М.: Республика, 1992. 512 с.

17. Хабермас Ю. Отношения между системой и жизненным миром в условиях позднего капитализма // THESIS. 1993. Вып. 2. С. 123-136. 
18. Хомяков А. С. Сочинения: в 2 т. / под ред. Е. В. Харитонова. М.: Медиум, 1994. T. $1.589 \mathrm{c}$.

19. Хоружий С. С. Идея соборности: ее православно-славянофильские истоки и ее перспективы в современном постсекулярном мире [Электронный ресурс] // Институт синергийной антропологии. URL: http://synergia-isa.ru/wp-content/uploads/2012/10/ horuzhy_sobornost_2012.pdf (дата обращения: 26. 03.2019).

\section{THE CONCEPT OF "SOBORNOST" IN RUSSIAN PHILOSOPHY}

Tatyana I. Barmashova

Dr. Sci. (Philos.), Prof.,

Krasnoyarsk State Agrarian University

90 Mira Prospect, Krasnoyarsk 660049, Russia

E-mail: tatibar910@mail.ru

Pavel V. Lomanov

Cand. Sci. (Culture), Teacher,

Lyceum No. 28,

17 Profsouzov St., Krasnoyarsk 660021, Russia

E-mail: lpv79@mail.ru

The article deals with the concept of "sobornost" in Russian philosophy, which reflects one of the main principles of social integration - the principle of spiritual community of people both in religious and secular contexts. The concept of sobornost in Russian philosophy affirms the norms of the highest morality, expressing the developed seld-consciousness and self-determination of the person in a collective experience as advancement to Divine truth. Such an interpretation makes it possible to comprehend the metaphysical depths of the personality, which are its essential aspects. The idea of sobornost has a significant impact on the development of humanitarian knowledge. We have emphasized a certain similarity of the idea of sobornost and the philosophical concepts of dialogue and communication of Western thinkers of the $20^{\text {th }}$ century: from representatives of religious existentialism (M. Buber, C. Jaspers, E. Levinas) to sociological and socio-philosophical theories of society in which pride of place goes to communication (T. Parsons, R. Merton, N. Luman, J. Habermas). The idea of sobornost is of great practical importance. The principle of the collective structure of society can become a means of harmonious consolidation of people, a basis for the establishment of national unity of the Russian state.

Keywords: sobornost; communication; dialogue; society; ecclesiology; theology; social philosophy; Russian philosophy; religious philosophy; Church; identity; lifeworld; system. 